\title{
A DEIXIS ANALYSIS OF ONLINE NEWSPAPER IN JAKARTA POST
}

\author{
Muchamad Rizal Febriza ${ }^{1}$ \\ ${ }^{1}$ IKIP Siliwangi \\ ${ }^{1}$ muchamadrizal205@ student.ikipsiliwangi.ac.id
}

\begin{abstract}
Deixis can be found in the spoken and written media. The use of proffer deixis concepts in the Newspaper media is influenced by background in its topic. This study aims to identify the deixis used in online Newspaper; Jakarta Post. This study was conducted by using the descriptive qualitative method and there are three steps to analyzing this article, 1). read the article, 2). found the deixis, 3). classified the types of deixis proposed by Alan Cruse (2000) theory. The result of a deixis analysis in an online Newspaper found 928 words such as; $70 \%$ person deixis, $12 \%$ temporal deixis, $10 \%$ discourse deixis, $5 \%$ social deixis, and 3\% spatial deixis. Person deixis is a type of deixis dominantly used in this online newspaper.
\end{abstract}

Keywords: Deixis, Online Newspaper, Pragmatics

\section{INTRODUCTION}

Pragmatics is a part of linguistic study that learn the relationship between the utterances and situation. According to Purba (2018), pragmatics is the study of the connection between the context and language that focuses on grammatical in the structure of language, it means the people can analyze the meaning of context by their statements. In addition, Yule (1996) states pragmatics is the investigation of the relations between the linguistic structures and its users only pragmatics permit a human into the analysis: their statements, purposes, objectives, and actions that perform while speaking.

Pragmatics has several parts to learn, one of them is deixis. Deixis is study on pragmatics to point out something via language. Deixis is important to learn about the language, especially in English as a foreign language because many people have difficulties to understand the meaning of the speaker, by using deixis it can be easy to communicate and focus on context. Based on Lyons cited in Setiakawanti \& Susanti (2018), deixis is study reference utilizing an expression whose interpretation is relative to the usual extra linguistic context of the terms, for example; who is talking, the time and spot of talking, the sign of the speaker or the existing area in the discourse. Based on all the definitions above, it can be concluded that pragmatics is the study of meaning depending on the context from speaker to hearer.

\section{Deixis}

Deixis is a study indicating or pointing something through language which can be used in oral or written utterances. Deixis is deictic expressions which depend on the speaker and addressee that share the spatial context and face-to-face with spoken interaction. According to Levinson (1983) in Viahapsari \& Parmawati (2020) deixis is a word which its reference always moves or changes depending on the contextto indicate person, place, time, social distinction, and role in discourse.In addition, Levinson (2004) cited in Lugina, Nuryulia, \& Suprijadi (2019), deixis 
is the study about deictic expressions in a language which refers to person, place, and time. It can be concerned that deixis is a special type of grammatical property that consist the several categories like person, place, and time. However, deixis in a communication role have some important matters to refers the object is talked about who or what (Afrilian, 2018). The use of deixis can be in word or phrase related directly with expressions of the person, spatial (place), temporal (time), social, and discourse deixis. Moreover, Abdulameer (2019), states that deixis is deictic expressions which refers to phrases or words that must be understood with clear information about the perspective, the use of deixis cannot be understood if the situation of information is unclear. Therefore, Cruse (2006) states the five types of deixis, there are person deixis, spatial (place) deixis, temporal (time) deixis, social deixis, and discourse deixis.

Person deixis includes the encoding of the participants and utterance from questions delivered. The person deixis is related to grammatical categories in person. Ibnus (2018), states that person deixis is related to the determining of the speech event role contributors when the situation in question is delivered. The use of person deixis is conveyed with the pronoun and possessive adjective, such as; First person (I, me, mine, myself), Second person (you, your, yourself, their, themselves, our, ourselves), and Third-person (she, he, it, him, his, her, himself, herself, its).

Spatial deixis also knows as place deixis. According to Levinson (2011) cited in Asmarita \& Haryudin (2019), spatial deixis is focused on qualified to a location in the utterances and explains the point of the location between speakers and listeners. In addition, spatial deixis can influenced the mentally and physically depending on the speaker's perspective. Therefore, Cruse (2006), states that spatial or place deixis is indicating the location in some spaces between the speakers and hearer. The example of spatial deixis is using adverb or demonstrative pronoun such as; Here, There, Those, etc.

Temporal deixis can be called as time deixis. According to Wicaksono (2019), temporal deixis or time deixis is involvement in the encoding of temporal time points and distance based on the context delivered by the speaker. The structures to communicate the temporal (time) deixis are the modifiers or adjectives of time in categorization like Yesterday, Now, Last year, Then, etc.

Social deixis is giving form based on social differences that refers to the role especially in several aspects related socially between the speaker and listener or the speaker has several refers (Levinson, 1985). Social deixis also known as the deixis which refers to the higher status of a person, social relationship or social level, this statement supported by Wicaksono (2019), social deixis can be a reference to the social character of person between the differences or refers contributors in the speech event. In addition, Cruse cited in Rizka et al. (2018), states that social deixis is an expression of word and has an utility is to show the situation of the referent or social status relative with the speaker. It involves a mark of social relationships with direct or slanted reference to the social status or role participants in the speech event. It can be concluded; the social deixis is the type of deixis refers to social relations in utterances.

Social deixis can be seen as follows :

a. Good day, madam.

b. Thank you, sir.

Discourse deixis is encoding to references to profit to an unfolding discourse which in the utterance to some profit of the discourse that contains the utterances. Deixis which demonstrates the reference marker in an area of talk. Discourse deixis is otherwise called "text deixis". Deixis discourse provides to facilitate the interpretation or understanding of the discourse that can be 
oral or written discourse (Wiguna, Anggraeni, Nuramalia, \& Sadikin, 2018). However, Anugrah (2018), states the discourse deixis is a forward-looking assertation refers to distinctive discourse that includes the utterances as the significance and indication of the text. The example of Discourse deixis can be seen as follows :

a. "This information is dangerous".

b. "That was a great time".

Based on this study above, the importance to learn the linguistic knowledge is important and one of is deixis which part of pragmatics study. In addition, the importance of deixis in online Newspaper can be distinguished the types of deixis like person deixis, spatial deixis, temporal deixis, social deixis, and discourse deixis for the readers. The objective of this study is the writer wants to discuss the deixis in online newspaper because the use of deixis was important in written utterances thus in writing sentences do not need to use a particular subject such as the name of the person, the name of the place, and a specified time and can be replaced with a pronoun to minimize the use of words so as it is not wasteful in mentioning the words repeated. It is supported by Hasanah cited in Lugina et al. (2019) the use of deixis will be easily to explained the function of deixis that using pronoun, demonstrative, and lexical future which has connected to utterance to understanding the reference that consist who, when, and where the utterance is expressed. Moreover, deixis can be used to referred something based on the context between the speaker and hearer. Hence, this study was focused on the 5 (five) types of deixis in online Newspaper; Jakarta Post and classified the type of deixis by reading the online article in Jakarta Post.

\section{METHOD}

This research was conducted by using qualitative as a method and using qualitative descriptive as a design. According to Creswell (2012) cited in Aryana \& Apsari (2018), Qualitative research is an analyzing of qualitative data involves to understanding how to interpreting of text and picture, so that can be determine the answer of your research question. This study aims to analyze the type of deixis that found in an online newspaper in Jakarta Post. This article was written by Astari (2019) entitled is "Deixis in Jakarta Post: Pancasila, Pluralism, and Election: Lessons from Istiqlal" available at https://www.thejakartapost.com/academia/2019/01/03/pancasila-pluralism-and-election-

lessons-from-istiqlal.html/. This study using Document Analysis as the instrument. The steps to analyze this data are reading the online article, finding and marking the deixis at the online newspaper, and classifying the types of deixis.

\section{RESULTS AND DISCUSSION}

\section{Results}

Deixis used in an online newspaper in Jakarta Post and the title is "Pancasila, Pluralism, and Election: Lessons from Istiqlal" written by Oryza Astari. The type of deixis is used in an online newspaper in Jakarta Post is presented in Table 1. 
Table 1. The analysis result of Deixis in Online Newspaper

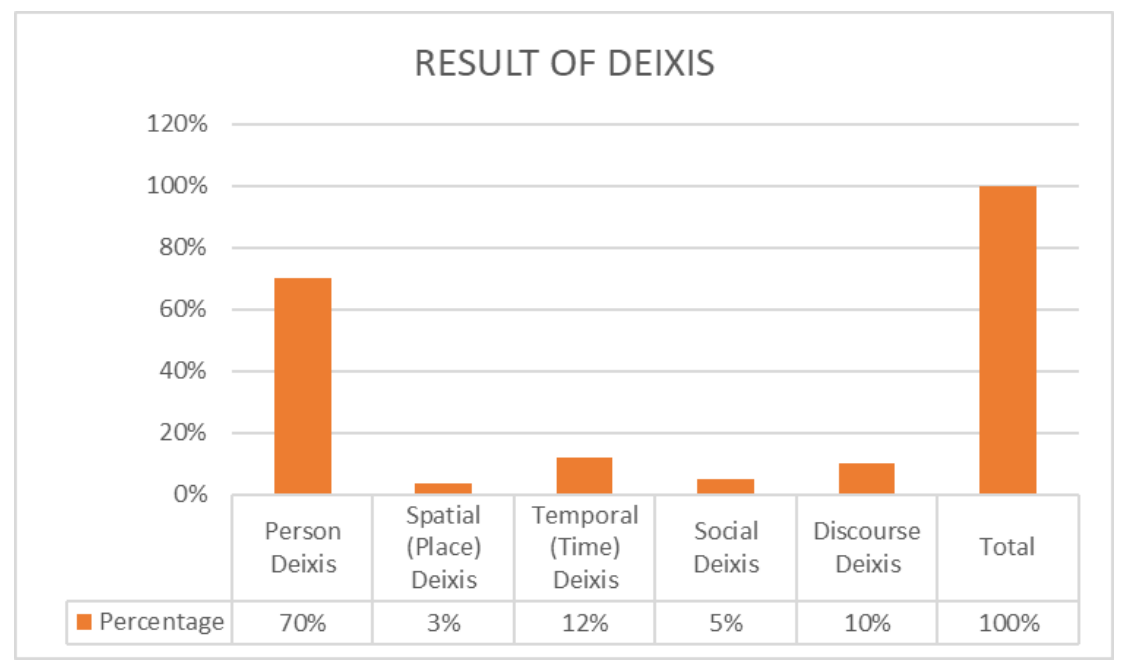

Table 1 shows the total of analysis Deixis of online newspaper in Jakarta Post. Based on Table 1 , person deixis is used 42 times and have percentage 70\%, spatial (place) deixis is used 2 times and has percentage $3 \%$, temporal (time) deixis is used 7 times and have percentage $12 \%$, social deixis is used 3 times and has percentage 5\%, and the last is discourse deixis is used 6 times and have percentage $10 \%$. The total of analysis deixis in an online article in Jakarta Post is $100 \%$. Based on the analysis in table 2 obtain above, the writer found person deixis, spatial (place) deixis, temporal (time) deixis, social deixis, and discourse deixis were written on the online newspaper in Jakarta Post.

\section{Person Deixis}

Table 2. Person Deixis found in Online Newspaper in Jakarta Post.

Types of Person Deixis

Number of Words

\begin{tabular}{cc}
\hline I & 15 \\
\hline My & 5 \\
\hline We & 3 \\
\hline Our & 3 \\
\hline Their & 3 \\
\hline He & 2 \\
\hline His & 6 \\
\hline It & 5 \\
\hline Total & $\mathbf{4 2}$
\end{tabular}

Table 2 reveals that the total number of person deixis found in the online newspaper in Jakarta Post is 42 times. The dominant in person deixis is "I" (15), "His" (6) "My" (5), "It "(5), "We", "Our", "Their" (3), and "He" (2)

Examples of person deixis can be seen as follows :

1. "I attended one of the most prestigious Islamic schools in Greater Jakarta".

The word "I" in this sentence refers to the person that will be attended to one of the most prestigious Islamic schools.

2. 'Despite NU's generally moderate outlook, Ma'ruf was infamous for his relatively hardline and controversial views against religious and gender including gays".

The word "his" in this sentence refers to Ma'ruf. 
3. "While I was only five years old was among the early signs the decline in our state ideology Pancasila, from which we have learnt respect for diversity".

The word "we" in this sentence refers to Indonesia's society must learn Pancasila and respect diversity.

\section{Spatial Deixis}

Table 3. Spatial Deixis found in Online Newspaper in Jakarta Post.

Types of Spatial Deixis

Number of Words

\begin{tabular}{cc}
\hline There & 1 \\
\hline Those & 1 \\
\hline Total & $\mathbf{2}$
\end{tabular}

Table 3 reveals that the total number of spatial deixis found in the online newspaper in Jakarta Post is 2 times. The dominant in spatial deixis are "There" (1), and "Those" (1).

Examples of spatial deixis can be seen as follows

1. 'At its current state, Indonesia' 2019 presidential race already shows a significant rollback of democratic values, there is still hope. "

The word "there" in this sentence refers to the Indonesian presidential race that shows the significant rollback of democracy.

2. "In the Istiqlal Mosque built across the Cathedral those of us who are part of the Muslim majority. "

The word "those" in this sentence refers to Istiqlal Mosque that built across the Cathedral.

\section{Temporal Deixis}

Table 4. Temporal Deixis found in Online Newspaper in Jakarta Post.

Types of Temporal Deixis Number of Words

\begin{tabular}{cl}
\hline Early & 3 \\
\hline Last Year & 1 \\
\hline Five Years Old & 1 \\
\hline Now & 1 \\
\hline Then & 1 \\
\hline Total & 7
\end{tabular}

Table 4 reveals that the total number of temporal deixis found in the online newspaper in Jakarta Post is 7 times. The dominant in temporal deixis is "Early" (3), and "Last Year", "Five Years Old", "Now", and "Then" (1) times.

Examples of temporal deixis can be seen as follows :

1. "It was early 2000s. "

This word "early" in this sentence refers to the build of the Islamic School in Greater Jakarta. 
2. "I saw a former classmate who now wears a hijab ".

This word "now" in this sentence refers to the former classmate that currently wears a hijab.

\section{Social Deixis}

Table 5. Social Deixis found in Online Newspaper in Jakarta Post. Types of Social Deixis Number of Words

\begin{tabular}{cc}
\hline Teacher & 1 \\
\hline President & 1 \\
\hline President and Legislative & 1 \\
\hline Total & $\mathbf{3}$
\end{tabular}

Table 5 reveals that the total number of social deixis found in the online newspaper in Jakarta Post is 3 times. The dominant in social deixis is "Teacher" (1), and "President", (1) "President and Legislative" (1) times.

Examples of social deixis can be seen as follows:

1. "I was also student who got into trouble for having parents who brought doughnuts decorated with candles for her birthday celebration at school. Candles, my teacher said, were "a Christian custom."

The word "teacher" in this sentence refers to a person that has a teacher and said to her students that Christian have special habits.

2. "As Indonesia prepares for upcoming 2019 presidential and legislative elections. " The word "presidential and legislative" in this sentence refers to Indonesia will prepare elections, especially elections of presidential and legislative in 2019.

3. "President Joko "Jokowi" Widodo chose as his running mate Ma'ruf Amin. " The word "president" in this sentence refers to one of the important people in Indonesia is president.

\section{Discourse Deixis}

Table 6. Discourse Deixis found in Online Newspaper in Jakarta Post.

\begin{tabular}{cc} 
Types of Discourse Deixis & Number of Words \\
\hline That & 4 \\
\hline This & 2 \\
\hline Total & $\mathbf{6}$
\end{tabular}

Table 6 reveals that the total number of discourse deixis found in the online newspaper in Jakarta Post is 6 times. The dominant in discourse deixis is "That" (4), and "This" (2)

Examples of discourse deixis can be seen as follows:

1. "This was not Jakarta I knew in the early 2000s. "

The word "this" in this sentence refers to Jakarta in year 2000s 
2. "Evidently, the mosque was built not just for Muslims, but all for Indonesians. That the mosque was commissioned by a president who desired to blend the faiths and philosophies."

The word "that" in this sentence refers to the mosque because this mosque is not only built for Muslims.

\section{Discussion}

Based on the result, the writer wants to discuss the result of deixis found in the online newspaper; Jakarta Post. In this study, there are several types of deixis like person deixis, spatial deixis, temporal deixis, social deixis, and discourse deixis. In addition, in this study person deixis was dominantly in this online article with percentage is $70 \%$. It evidenced by Asmarita \& Haryudin (2019) that type of deixis especially person deixis is more often to use in written utterances or online article because the using of person deixis can be contingent on the speaker that has a position as a deictic center. The speaker as a first person or subject can speak to the second person as a listener or might talk to the third person in a certain situation so that making it easier for readers to analyze the use of person deixis in one article. The writer thinks the author of this online article more frequently using person deixis in her article because she has a position as a citizen that who wants to inform her experience via Jakarta Post. Based on previous research that using deixis in written utterances especially in song lyrics that are written by Rizka, Setiadi, \& Ilza (2018), found the person deixis is dominantly in Ed Sheeran song lyrics in Divide album because the person deixis almost dominantly in all songs with a percentage is $28 \%$. In addition, Setiakawanti \& Susanti (2018) found the person deixis is dominantly in the articles of Jakarta Sport with a percentage is 66,5\%. Moreover, the types of deixis that analysis in articles online, song lyrics, and movie script are person deixis almost dominantly found in written utterances. Therefore, in the online article should not use "I", because the word "I" showed the author is not a professional author. It can be concluded that the word "I" in the online article should be avoided because has possibilities this article publish based on the citizen's experience that published in the article in Jakarta Post and share the citizen's experience through Jakarta Post website.

\section{CONCLUSION}

Based on the results of this study about A Deixis Analysis of Online Newspaper in Jakarta Post, it can be concluded that were five types of deixis namely Person Deixis, Spatial Deixis, Temporal Deixis, Social Deixis, and Discourse Deixis. The analysis found that out of 928 words in this online article with the title is "Deixis in Jakarta Post: Pancasila, Pluralism, and Election: Lessons from Istiqlal". The most dominantly is $70 \%$ Person Deixis, $12 \%$ Temporal Deixis, $10 \%$ Discourse Deixis, 5\% Social Deixis, and 3\% Spatial Deixis. Therefore, this study will be helped to understand the readers to read the article correctly and clearly about deixis in an online Newspaper; Jakarta Post.

\section{ACKNOWLEDGMENTS}

The writer would like to express and say thanks to Allah SWT who has given health thus this article can be finished. Also, thank you for writer's family who gives writer appreciation, support, and motivation. This article will not be finished without help, guidance, support, and suggestion from writer's supervisor Bapak Dasep Suprijadi, M.Pd., thank you for the guidance, kindness, correcting and help the writer to finish this article. 


\section{REFERENCES}

Abdulameer, T. A. S. A. (2019). A Pragmatic Analysis of Deixis in a Religious Text. International Journal of English Linguistics, 9(2), 292-306. https://doi.org/10.5539/ijel.v9n2p292

Afrilian, W. (2018). Deixis In Judith Mcnaught's Night Whispers Novel. The State Islamic University Sulthan Thaha Saiffudin Jambi.

Anugrah, S. V. (2018). Analysis Of Deixis In The Story Selected From Christian Bible, Genesis. PROJECT (Professional Journal of English Education), 1(5), 664-670.

Aryana, S., \& Apsari, Y. (2018). Analyzing Teacher's Difficulties In Teaching Listening. ELTIN Journal, 6(11), 100-106.

Asmarita, A., \& Haryudin, A. (2019). An Analysis Deixis In Ridwan Kamil's Speech At The Asia Africa Conference (KAA). PROJECT (Professional Journal of English Education), 2(5), 622-627.

Astari, O. (2019). Pancasila, pluralism and election: Lessons from Istiqlal. Retrieved April 29, 2020, from https://www.thejakartapost.com/academia/2019/01/03/pancasila-pluralismand-election-lessons-from-istiqlal.html

Cruse, A. (2006). A Glossary of Semantics and Pragmatics. Edinburgh: Edinburgh Unviersity Press.

Ibnus, N. (2018). The Use Of Deixis In Narrative Texts In The Bse English Textbook's “ Developing English Competencies 1 ." Philosophica, I(1), 20-24.

Levinson, S. C. (1985). PRAGMATICS (First Edit). London New York New Rochelle Melbourne Sydney: Cambridge University Press.

Lugina, G., Nuryulia, E., \& Suprijadi, D. (2019). Deixis In The Legend Of Lake Toba Story. PROJECT (Professional Journal of English Education), 2(5), 640-644.

Purba, D. (2018). Deixis In John Legend's Songs. Jurnal Littera, 1, 76-84.

Rizka, D., Nasution, A., Setiadi, G., \& Ilza, S. S. (2018). Deixis Analysis In The Song Lyrics Of Ed Sheeran's. English Language and Literature International Conference (ELLic), 2, 376-382.

Setiakawanti, R. N., \& Susanti, E. (2018). Analysis Pragmatic Study On Deixis In The Articles Jakarta Sport. PROJECT (Professional Journal of English Education), 1(6), 757-762.

Viahapsari, E., \& Parmawati, A. (2020). Analysis The Type Of Deixis In The Main Character On The Movie I Leave My Heart In Lebanon. PROJECT (Professional Journal of English Education), 3(3), 388-394.

Wicaksono, G. A. (2019). Students ' Competence In Interpreting Deixis In Descriptive Text On Pragmatics Course Of English. Jurnal Penelitian Humaniora, 20(1), 10-21.

Wiguna, A., Anggraeni, H., Nuramalia, R., \& Sadikin, I. S. (2018). Deixis In Maleficent Movie Script. PROJECT (Professional Journal of English Education), 1(2), 133-138.

Yule, G. (1996). The Study of Language (Fourth Edi). Cambridge University: United States of America by Cambridge University Press, New York. 